\title{
Deficits in Cognition and Synaptic Plasticity in a Mouse Model of Down Syndrome Ameliorated by $\mathrm{GABA}_{\mathrm{B}}$ Receptor Antagonists
}

\author{
Alexander M. Kleschevnikov, ${ }^{1,4}$ Pavel V. Belichenko, ${ }^{1,4}$ Mehrdad Faizi, ${ }^{2}$ Lucia F. Jacobs, ${ }^{3}$ Khin Htun, ${ }^{2}$ \\ Mehrdad Shamloo, ${ }^{2}$ and William C. Mobley ${ }^{1,4}$ \\ ${ }^{1}$ Department of Neurosciences, University of California, San Diego, La Jolla, California 92093, ${ }^{2}$ Behavioral and Functional Neuroscience Laboratory, \\ Institute of Neuro-Innovation and Translational Neurosciences, Stanford University, Stanford, California 94305-5400, ${ }^{3}$ Department of Psychology, \\ University of California, Berkeley, California 94720-1650, and ${ }^{4}$ Down Syndrome Center for Research and Treatment, University of California, San Diego, La \\ Jolla, California 92093
}

Cognitive impairment in Down syndrome (DS) is characterized by deficient learning and memory. Mouse genetic models of DS exhibit impaired cognition in hippocampally mediated behavioral tasks and reduced synaptic plasticity of hippocampal pathways. Enhanced efficiency of GABAergic neurotransmission was implicated in those changes. We have recently shown that signaling through postsynaptic $\mathrm{GABA}_{\mathrm{B}}$ receptors is significantly increased in the dentate gyrus of Ts65Dn mice, a genetic model of DS. Here we examined a role for $\mathrm{GABA}$ receptors in cognitive deficits in DS by defining the effect of selective $\mathrm{GABA}_{\mathrm{B}}$ receptor antagonists on behavior and synaptic plasticity of adult Ts65Dn mice. Treatment with the $\mathrm{GABA}_{\mathrm{B}}$ receptor antagonist CGP55845 restored memory of Ts65Dn mice in the novel place recognition, novel object recognition, and contextual fear conditioning tasks, but did not affect locomotion and performance in T-maze. The treatment increased hippocampal levels of brain-derived neurotrophic factor, equally in $2 \mathrm{~N}$ and Ts65Dn mice. In hippocampal slices, treatment with the $\mathrm{GABA}_{\mathrm{B}}$ receptor antagonists CGP55845 or CGP52432 enhanced long-term potentiation (LTP) in the Ts65Dn DG. The enhancement of LTP was accompanied by an increase in the NMDA receptor-mediated component of the tetanus-evoked responses. These findings are evidence for a contribution of $\mathrm{GABA}_{\mathrm{B}}$ receptors to changes in hippocampal-based cognition in the Ts65Dn mouse. The ability to rescue cognitive performance through treatment with selective $\mathrm{GABA}_{\mathrm{B}}$ receptor antagonists motivates studies to further explore the therapeutic potential of these compounds in people with DS.

\section{Introduction}

Intellectual deficiency in Down syndrome (DS) features abnormalities in learning (Gardiner et al., 2010; Lott and Dierssen, 2010) and, most notably, in hippocampus-dependent explicit memory (Carlesimo et al., 1997; Vicari, 2001). Morphological, physiological, and behavioral data consistently point to impaired function of the hippocampus and dentate gyrus (DG) (Sylvester, 1983; Nadel, 2003; Haydar and Reeves, 2012). There is widespread agreement that deficits in memory contribute significantly to the overall burden of intellectual difficulties in people with DS (Contestabile et al., 2010).

Mouse genetic models have provided important insights into the genes and mechanisms responsible for DS-specific changes (Reeves, 2006; Hanson et al., 2007; Moore and Roper, 2007;

\footnotetext{
Received April 4, 2012; revised May 15, 2012; accepted May 20, 2012.

Author contributions: A.M.K. and W.C.M. designed research; A.M.K., M.F., K.H., and M.S. performed research; LF.J. contributed unpublished reagents/analytic tools; A.M.K. and P.V.B. analyzed data; A.M.K. and W.C.M. wrote the paper.

This work was supported by grants from NIH (NS 38869, NS055371), the Hillblom Foundation, The Anna and John J. Sie Foundation, The Thrasher Foundation, and the Down Syndrome Research and Treatment Foundation.

Correspondence should be addressed to Alexander Kleschevnikov, Department of Neurosciences, University of California, San Diego, 9500 Gilman Drive, La Jolla, California, 92093. E-mail: akleschevnikov@yahoo.com.

DOI:10.1523/JNEUROSCI.1673-12.2012

Copyright $\odot 2012$ the authors $\quad 0270-6474 / 12 / 329217-11 \$ 15.00 / 0$
}

Salehi et al., 2007; Gotti et al., 2011; Liu et al., 2011; Popov et al., 2011; Kleschevnikov et al., 2012b; Zhang et al., 2012). The Ts65Dn mouse bears an extra copy of approximately half the genes homologous to those on human chromosome 21 (Davisson et al., 1993; Olson et al., 2007; Sturgeon and Gardiner, 2011). These mice recapitulate a number of behavioral and physiological features of DS, including deficits in hippocampal function and impaired learning and memory (Holtzman et al., 1996; Dierssen et al., 2001; Hyde et al., 2001; Galdzicki and Siarey, 2003; Incerti et al., 2011; Shichiri et al., 2011). Long-term potentiation (LTP), a cellular model for learning and memory, is impaired in the CA1 and DG of Ts65Dn and other DS models (Siarey et al., 1997; Kleschevnikov et al., 2004; Costa and Grybko, 2005; P.V. Belichenko et al., 2007; Fernandez et al., 2007; Yu et al., 2010). These changes were linked to alterations in the properties of inhibitory neurotransmission (Kleschevnikov et al., 2004). Indeed, it was subsequently shown that hippocampal synaptic plasticity and cognition can be regulated by modulating inhibitory efficiency in mouse models of DS (Kleschevnikov et al., 2004; Costa and Grybko, 2005; Fernandez and Garner, 2007b; Rueda et al., 2008; P.V. Belichenko et al., 2009; Begenisic et al., 2011; Braudeau et al., 2011b).

Recently we demonstrated that signaling through postsynaptic $\mathrm{GABA}_{\mathrm{B}}$ receptors is significantly enhanced in the Ts65Dn DG 
(Kleschevnikov et al., 2012a). Other researchers observed that in the CA1 region the balance between $G_{A B A}$ and $G_{A B A}$ receptor-mediated inhibition is altered in favor of the latter in a pathway-specific manner (Best et al., 2012). These changes were linked to DS-specific genetic alterations owing to triplication of Kcnj6 and subsequent overexpression of Kir3.2 subunits of the inwardly rectifying potassium channels, postsynaptic effectors of the $\mathrm{GABA}_{\mathrm{B}}$ receptors (Kleschevnikov et al., 2005; Harashima et al., 2006). The role of $\mathrm{GABA}_{\mathrm{B}}$ receptors in cognitive impairment in DS has not yet been investigated behaviorally.

Herein we examine the effect of selective $G_{A B A}$ receptor antagonists on cognition and synaptic plasticity of Ts65Dn mice. Suppression of $\mathrm{GABA}_{\mathrm{B}}$ receptors significantly improved performance of Ts65Dn mice in behavioral tests for short- and longterm memory, but did not affect locomotor activity and working memory. Significantly, the improvement in hippocampusmediated behaviors seen in vivo was complemented by improved LTP and increased NMDA receptor-mediated responses after suppressing $\mathrm{GABA}_{\mathrm{B}}$ receptors in hippocampal slices. Thus, $\mathrm{GABA}_{\mathrm{B}}$ receptors represent a potential therapeutic target for reversing cognitive deficits in people with DS.

\section{Materials and Methods}

Animals. Segmental trisomy 16 (Ts65Dn) mice were obtained by mating female carriers of the $17^{16}$ chromosome (B6EiC3H-a/A-Ts65Dn) with (C57BL/6JEi X C3H/HeJ) F1 (JAX \#JR1875) males (Davisson et al., 1993). Ts65Dn mice are thus maintained on the B6/C3H background. Diploid (2N) littermate mice served as control. For genotyping, tail samples were used to extract genomic DNA; a quantitative PCR protocol developed by the The Jackson Laboratory (http://www.jax.org/cyto/ quanpcr.html) was used to measure expression of the $M x 1$ gene, which is present in three copies in Ts65Dn. All mice were also screened for retinal degeneration due to Pde6brd1 homozygosity (Bowes et al., 1993), and only animals free of retinal degeneration were used. Mice were males and housed $2-5$ per cage with a $12 \mathrm{~h}$ light/dark cycle and ad libitum access to food and water. The experiments were conducted in accordance with the $\mathrm{NIH}$ guidelines and with an approved protocol from the Stanford University Institutional Animal Care and Use Committee.

Behavioral testing. All mice were exposed to behavioral tests starting at 2-3 months of age. Each mouse was handled for $5 \mathrm{~min}$, twice a day, during the $7 \mathrm{~d}$ that preceded testing and for $3 \mathrm{~d}$ in between tests. All tests were performed during the light cycle between 7:00 A.M. and 7:00 P.M. To minimize olfactory cues from previous trials, each apparatus was thoroughly cleaned with $10 \%$ ethanol after each animal. On the day of testing, mice were left in their home cages in the room used for the experiment for $2 \mathrm{~h}$ before the onset of the study for habituation. CGP55845 (0.5 mg/kg suspended in saline, $10 \mathrm{ml} / \mathrm{kg})$, or the equivalent volume of saline only, was injected intraperitoneally $2-3 \mathrm{~h}$ before the testing. For chronic tests, the drug was injected once a day for 3 weeks. Body weight, which was measured weekly, was not affected by the treatment. All behavioral tests and procedures were performed by personnel blind to both genotype and treatment group.

Spontaneous locomotor activity was evaluated in square Plexiglas chambers $(43.2 \times 43.2 \times 20 \mathrm{~cm})$ equipped with three planes of infrared detectors (Med Associates). The area of the chamber was divided virtually on center $(20 \times 20 \mathrm{~cm}$, zone 2$)$ and periphery (the rest of the chamber, zone 1). The activity chamber was located within sound-attenuating boxes $(66 \times 55.9 \times 55.9 \mathrm{~cm})$. For testing, an animal was placed in the center of the testing arena under bright ambient light and allowed to move ad libitum for $10 \mathrm{~min}$. The movements were monitored by an automated tracking system (Med Associates Activity Monitor, version 5.93.773).

T-maze testing was performed as previously described (N.P. Belichenko et al., 2009; Faizi et al., 2011). The T-maze had three equal arms (30 $\mathrm{cm}$ length, $10 \mathrm{~cm}$ width, and $20 \mathrm{~cm}$ height). It was made of opaque acrylic (Plexiglas) and had three gates: in the start arm and in the two goal arms. A mouse was placed at the beginning of the start arm with its back to the closed door. The trial started with opening of the start door, after which the mouse ran down the start arm to choose the right or left goal arm. After the mouse had entered one goal arm, defined as the entry of all four limbs, the door to the other goal arm was closed. This allowed the mouse to explore the arm entered and to return to the start arm. When the mouse eventually returned to the start arm, the start door was closed and the doors of the goal arms were then opened. The procedure was repeated 11 times (i.e., 10 alternations) for 3 consecutive days, for a total of 30 alternations. The spontaneous alternation score was defined as the number of left-right and right-left alternations, expressed as a percentage of the total number of possible alternations.

Novel object recognition and novel place recognition were tested using the Bevins and Besheer (2006) protocol. Mice were habituated in a black Plexiglas rectangular chamber $(31 \times 24 \mathrm{~cm}$, height $27 \mathrm{~cm})$ for $10 \mathrm{~min}$ on 2 consecutive days under dim ambient light conditions. The activity of mice was recorded with a video camera. Each test had two phases: acquisition and testing. For acquisition, two identical objects were placed in diagonally opposite corners of the chamber $8-9 \mathrm{~cm}$ from the walls. A mouse was placed at the midpoint between the objects. After allowing 10 min to explore the objects, the mouse was returned to the colony. The testing was performed $10 \mathrm{~min}$ or $24 \mathrm{~h}$ after the acquisition. In the tests for place recognition, one of the objects was moved in a new location in another corner of the chamber, while the other object remained at its former spatial location. In the tests for novel object recognition, one of the objects was replaced with a novel object of the same height and volume but different shape and appearance. For testing, the mouse was again placed in the chamber to explore the objects for $3 \mathrm{~min}$. The amount of time spent exploring each object (nose sniffing and head orientation within $<1.0 \mathrm{~cm}$ ) was recorded and evaluated by operators blinded to genotype and treatment. The discrimination index was computed as $R(\%)=T_{\text {new }}{ }^{*} 100 \% /\left(T_{\text {new }}+T_{\text {old }}\right)$, where $T_{\text {new }}$ is the time spent exploring the new or moved object, and $T_{\text {old }}$ is the time spent exploring the familiar or unmoved object.

Fear conditioning. The test was performed using chambers from Coulbourn Instruments. Day 1 training consisted of five pairs of tone and electrical footshocks given in the conditioning context. Once placed in the conditioning chamber, mice were allowed to explore ad libitum for 3 $\mathrm{min}$. Then a $20 \mathrm{~s}$ tone $(2 \mathrm{kHz} ; 70 \mathrm{~dB})$ was played that coterminated with a footshock $(0.5 \mathrm{~mA}, 50 \mathrm{~Hz}, 2 \mathrm{~s})$. This procedure was repeated five times with a $1 \mathrm{~min}$ interval. Mice remained in the chamber for $30 \mathrm{~s}$ following the last shock. On day 2 ( $24 \mathrm{~h}$ after the training), a recent tone fear memory was measured in a distinct chamber that had new olfactory, tactile, and visual cues. The mice were placed in this new chamber for 3 min and were subsequently presented three tones identical to those used in the training session. On day 3 ( $48 \mathrm{~h}$ after the training), a recent contextual fear memory was tested by placing the mice in the conditioning chamber for $3 \mathrm{~min}$. Freezing, defined as the complete lack of motion for a minimum of $0.75 \mathrm{~s}$, was recorded with a video camera and analyzed by FreezeFrame software (Actimetrics). The percentage of freezing during each period of the experiment was reported.

Western blot. The hippocampi were dissected on an ice-cold preparation table and homogenized in radioimmunoprecipitation assay buffer (50 mm Tris- $\mathrm{HCl}, 1 \% \mathrm{NP}-40,0.25 \%$ Na-deoxycholate, $150 \mathrm{~mm} \mathrm{NaCl}, 1$ mM EDTA, $1 \mathrm{~mm}$ PMSF, $1 \mathrm{~mm}$ Na3VO4, $1 \mathrm{~mm} \mathrm{NaF}$ ) with $1 \mathrm{mg} / \mathrm{ml}$ protease inhibitor mixture (aprotinin, leupeptin, pepstatin). The protein concentrations were determined using BCA protein assay kit (Pierce). $\beta$-Tubulin was used as a reference protein. Twenty microliters $(1 \mathrm{mg} / \mathrm{ml})$ of total protein per lane was loaded onto precast $4-12 \%$ Bis-Tris gels (Invitrogen) and separated by electrophoresis at $90 \mathrm{~V}$ for $\sim 2 \mathrm{~h}$. Proteins were transferred to a low-fluorescent, hydrophobic polyvinylidene difluoride membrane with $0.2 \mu \mathrm{m}$ pore size (Hybond-LFP; GE Healthcare), and the membranes were blocked with $4 \%$ nonfat milk in TBS-T solution (20 mu Tris- $\mathrm{HCl}, 150 \mathrm{~mm} \mathrm{NaCl}, 0.1 \%$ Tween 20, pH 7.6). Membranes were then incubated with rabbit polyclonal primary antibody anti-brainderived neurotrophic factor (BDNF) (sc-546 [N-20], 1:200; Santa Cruz Biotechnology), or mouse monoclonal antibody anti- $\beta$-tubulin (1:2000; Sigma). The blots were washed in TBS-T $(3 \times 10 \mathrm{~min})$ followed by incubation with goat anti-rabbit IgG-horseradish peroxidase conjugates at a dilution of 1:5000. The blots were washed in TBS-T and then developed 
A

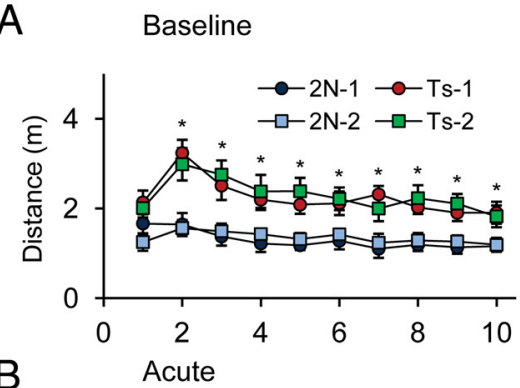

B

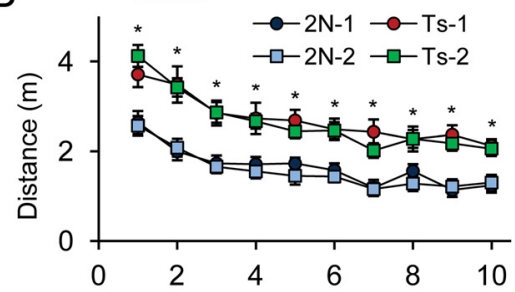

C

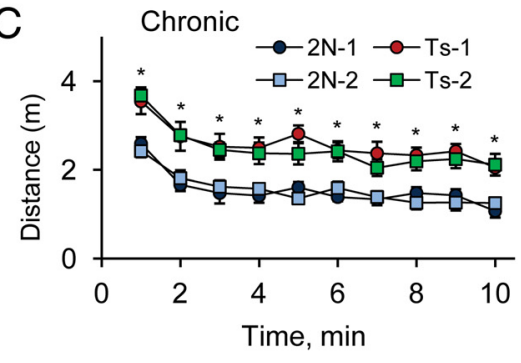

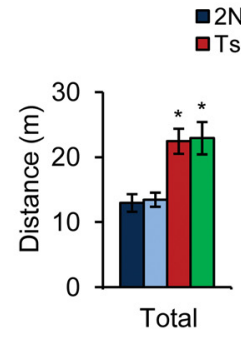

$\square 2 \mathrm{~N}-1 \quad \square 2 \mathrm{~N}-2$

Ts-1 $\quad$ पTs-2
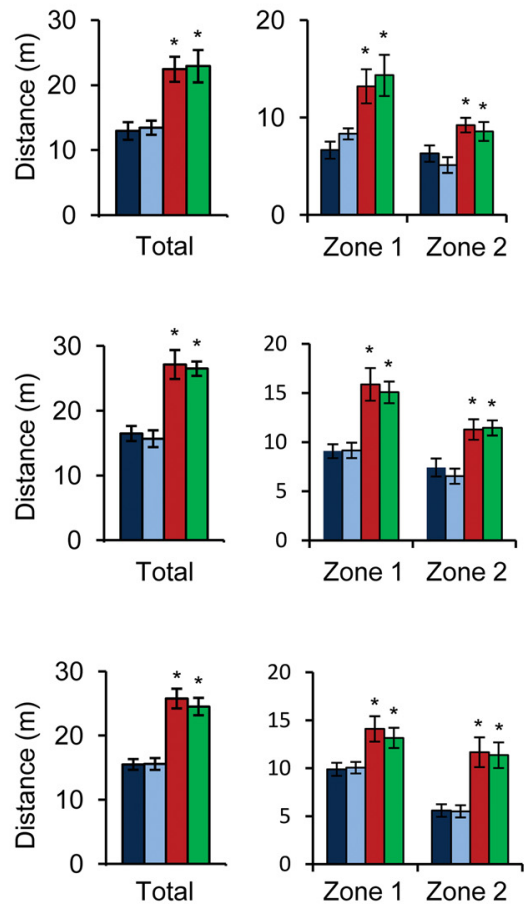

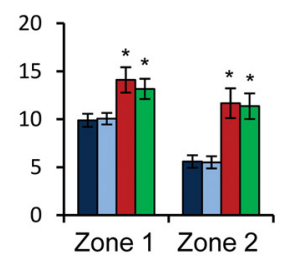

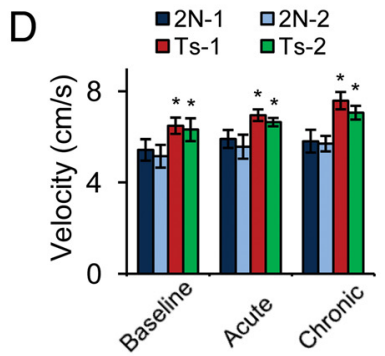
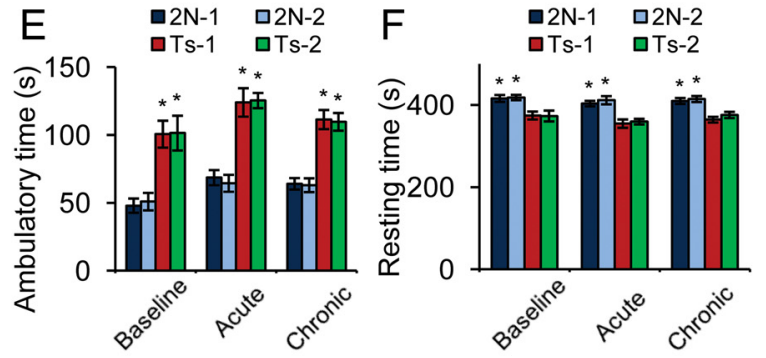

Figure 1. Spontaneous locomotor activity was enhanced in Ts65Dn mice, but it was not affected by the $\mathrm{GABA}_{\mathrm{B}}$ receptor antagonist CGP55845. $\boldsymbol{A}-\boldsymbol{C}$, Distance moved in the activity chamber at baseline $(\boldsymbol{A})$ and during acute $(\boldsymbol{B})$ and chronic $(\boldsymbol{C})$ phases of the treatment averaged for 1 min periods (left) and for the total 10 min testing period (right). Ts65Dn mice moved significantly greater distances both at the periphery (zone 1 ) and in the center (zone 2). During the acute $(\boldsymbol{B})$ and chronic $(\boldsymbol{C})$ tests, mice from Groups $2 \mathrm{~N}-1$ and Ts- 1 were treated with vehicle, while mice from Groups $2 \mathrm{~N}-2$ and Ts-2 with CGP55845. The treatment had no effect on the distance moved by $2 \mathrm{~N}$ or Ts65Dn mice. $\boldsymbol{D}$, Averaged velocity of movement. $\boldsymbol{E}$, Ambulatory time. $\boldsymbol{F}$, Resting time. All of these parameters were abnormal in Ts65Dn mice, but not affected by the treatment. Mean \pm SEM; $n=12-15$ per group. ${ }^{*} p<$ 0.03 for $2 \mathrm{~N}$ versus Ts65Dn groups.

with SuperSignal (Pierce). Immunoblots were scanned with Moleculer Imager ChemiDoc XRS ${ }^{+}$(Bio-Rad) and the images were analyzed with Image (NIH).

Electrophysiology. Transverse hippocampal slices were prepared as previously described (Salehi et al., 2009; Kleschevnikov et al., 2012a). Adult (3- to 5-month-old) male mice were anesthetized with isoflurane before decapitation. The brain was quickly removed and immersed for $2 \mathrm{~min}$ in ice-cold artificial CSF (ACSF) containing the following (in mM): 119 $\mathrm{NaCl}, 2.5 \mathrm{KCl}, 2.5 \mathrm{CaCl}_{2}, 1.3 \mathrm{MgSO}_{4}, 1 \mathrm{NaH}_{2} \mathrm{PO}_{4}, 26 \mathrm{NaHCO}_{3}$, and 10 glucose, osmolarity $310 \mathrm{mOsm}$, continuously bubbled with $95 \% \mathrm{O}_{2}-5 \%$ $\mathrm{CO}_{2}, \mathrm{pH}$ 7.4. The hippocampus was extracted and cut in ice-cold ACSF with a vibratome (Leica 1000) into $350-\mu \mathrm{m}$-thick slices, which were allowed to recover in oxygenated ACSF at room temperature for at least $2 \mathrm{~h}$ before experimental recordings.

A slice was transferred into the recording submerged chamber and superfused with ACSF at a constant rate of $2.5 \mathrm{ml} / \mathrm{min}$ at $32^{\circ} \mathrm{C}$. Recording electrodes were made of borosilicate glass capillaries (1B150F; World Precision Instruments) and filled with $2 \mathrm{M} \mathrm{NaCl}$ (resistance 0.3-0.5

$\mathrm{M} \Omega$ ). Monopolar stimulating electrodes were made of $\mathrm{Pt} / \mathrm{Ir}$ wires of diameter $25.4 \mu \mathrm{m}$ (PTT0110; World Precision Instruments) and had $100 \mu \mathrm{m}$ long exposed tips. The stimulating electrode was inserted under visual control perpendicular to the slice surface into the middle molecular layer; the recording electrode was inserted into the granule cell layer of the DG upper blade. The distance between the electrodes was $250-300 \mu \mathrm{m}$. The initial slope of field EPSP (fEPSP) was measured at latencies $0.1-0.9 \mathrm{~ms}$. Testing stimuli (duration 100 $\mu \mathrm{s}$, currents $80-100 \mu \mathrm{A}$ ) evoked field responses with amplitudes of $70-80 \%$ of maximum. LTP was induced by tetanizations consisting of four trains of stimuli $(0.5 \mathrm{~s} \times 100$ $\mathrm{Hz}$ ) applied with a $10 \mathrm{~s}$ interval.

Chemicals. $\mathrm{GABA}_{\mathrm{B}}$ receptor antagonists CGP52432 and CGP55845 were purchased from Tocris Cookson. All other chemicals were purchased from Sigma-Aldrich.

Statistics. Two-way ANOVA followed by Turkey's post hoc test was used to evaluate the data. The data are presented as mean \pm SEM.

\section{Results}

$\mathrm{GABA}_{\mathrm{B}}$ receptor antagonist treatment rescued cognitive deficits of Ts65Dn mice in hippocampally mediated memory tasks

Balance between excitatory and inhibitory neurotransmission is a necessary prerequisite for activity-dependent synaptic plasticity and, hence, efficient learning and memory. Previous studies in Ts65Dn mice pointed to enhanced GABAergic signaling as possibly responsible for reduced learning and memory. Because enhancement in GABAergic signaling is due, at least in part, to excessive activation of $\mathrm{GABA}_{\mathrm{B}}$ receptors, we tested the possibility that antagonists of the $\mathrm{GABA}_{\mathrm{B}}$ receptors could improve learning and memory in mouse models of DS. Thus, we examined what effect if any might result from inhibiting $\mathrm{GABA}_{\mathrm{B}}$ receptors by treating Ts65Dn and $2 \mathrm{~N}$ mice with the high-affinity selective $\mathrm{GABA}_{\mathrm{B}}$ receptor antagonist CGP55845 (0.5 $\mathrm{mg} / \mathrm{kg}$, i.p. injections). Possible drug effects on locomotor activity and general exploratory habits were first evaluated. This was followed by evaluation of the drug effects on working short- and long-term memory.

\section{Spontaneous locomotor activity}

It was previously observed in mice that $\mathrm{GABA}_{\mathrm{B}}$ receptor antagonists, administered at high doses, may increase spontaneous locomotor activity (Colombo et al., 2001). Such changes would influence general exploratory habits and, perhaps, performance of animals in tests for learning and memory. To monitor possible changes in locomotion, the mice were tested in the activity chamber three times: before administration of the drug (baseline) and during the acute (1-2 d) and chronic ( 3 weeks) phases of treatment. In all three tests, Ts65Dn mice showed significantly greater locomotor activity than $2 \mathrm{~N}$ controls (Fig. 1). The most notable difference was observed for distance traveled (Fig. $1 A-C$ ) and ambulatory time (Fig. $1 E$ ), both of which were approximately 


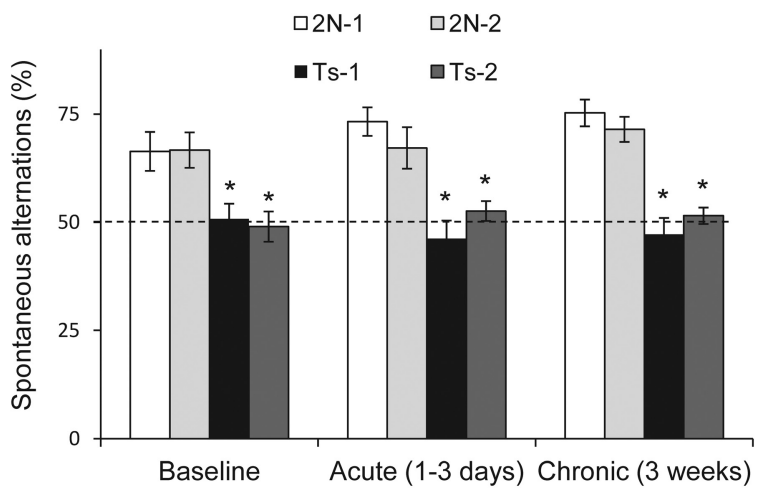

Figure 2. Performance in T-maze was not affected by treatment with CGP55845. The baseline rate of spontaneous alternations was greater in $2 \mathrm{~N}$ versus Ts65Dn mice. Acute and chronic treatment with CGP55845 had no effect on the alternation rate. Groups $2 \mathrm{~N}-1$ and Ts- 1 were treated during the acute and chronic phase with the vehicle, Groups $2 \mathrm{~N}-2$ and Ts-2 with CGP55845. * $p<0.01$ for all $2 \mathrm{~N}$ versus Ts65Dn groups.

twice greater in Ts65Dn than in $2 \mathrm{~N}$ mice. Average velocity of movement also was significantly greater in Ts65Dn mice (Fig. $1 D$ ), while resting time was reduced (Fig. $1 F$ ). Neither acute nor chronic treatment with the $\mathrm{GABA}_{\mathrm{B}}$ receptor antagonist had an effect on these measures; e.g., total distance traveled, distance traveled at the periphery (zone 1), or distance traveled in the center (zone 2) of the activity chamber showed no difference between the CGP and Veh groups during the acute (Fig. $1 B$ ) and chronic (Fig. $1 C$ ) phases of treatment in both $2 \mathrm{~N}$ and Ts65Dn mice. Also, the ratio of the distances traveled in zones 1 and 2 (zone1/zone 2) was not different in Ts65Dn versus $2 \mathrm{~N}$ mice ( $p=$ $0.36)$, and it was not affected by the treatment in both $2 \mathrm{~N}$ and Ts65Dn ( $p=0.24-0.98)$. Interestingly, the distance moved by Ts65Dn and $2 \mathrm{~N}$ mice during the first minute was smaller in baseline test (Fig. $1 A$ ) than in acute and chronic tests (Fig. $1 B, C$ ), but this change was similar for the groups treated with CGP and vehicle. Thus, suppression of $\mathrm{GABA}_{\mathrm{B}}$ receptors had no effect on locomotion or exploratory habits of either Ts65Dn or $2 \mathrm{~N}$ mice.

\section{Working memory}

Working memory was evaluated by measuring the rate of spontaneous alternations in T-maze. Consistent with previous findings, Ts65Dn mice showed a severe deficit in this behavioral task (Fig. 2). Thus, the baseline rate of spontaneous alternations was $2 \mathrm{~N}: 66.5 \pm 2.9 \%, n=25$, and Ts65Dn: $49.9 \pm 2.4 \%, n=26, p=$ 0.001. Treatment with CGP55845 had no effect on performance of Ts65Dn or $2 \mathrm{~N}$ mice; the alternation rates following the acute and the chronic treatment did not differ from the baseline (Fig. 2 ). Thus, working memory of Ts65Dn and $2 \mathrm{~N}$ mice was not affected by the antagonist of the $\mathrm{GABA}_{\mathrm{B}}$ receptors.

\section{Short-term memory}

Short-term memory was evaluated using two behavioral paradigms, novel place recognition and novel object recognition, and both tasks have a retention period of 10 min (Fig. $3 \mathrm{~A}, \mathrm{~B}$ ). Although both of these tasks require involvement of the hippocampus, the place recognition paradigm is expectedly more sensitive to hippocampal dysfunction due to the necessity of spatial orientation during the test. The acquisition phase was similar in both tasks: a mouse was placed in the center of the acquisition box and allowed for $10 \mathrm{~min}$ to investigate two identical objects. All groups of Ts65Dn and $2 \mathrm{~N}$ mice, treated with the drug or vehicle, spent on average equal time investigating the objects (Fig. 3C,E). To test for side preference, the discrimination indexes were computed for the acquisition phase. The averaged values of the indexes were not different from $50 \%$ for all groups of animals, suggesting no side preference during the acquisition phase $(p=0.4-0.9)$. These data suggest that $2 \mathrm{~N}$ and Ts65Dn mice were equal in attention paid to the objects, and that treatment had no effect on baseline exploratory behavior.

After the retention period, in the place recognition task one of the objects was moved in a new location and the mouse was again allowed to explore for $3 \mathrm{~min}$ (Fig. $3 \mathrm{~A}$, testing). Total time spent on exploration of objects during this phase was again similar in all groups of animals: $2 \mathrm{~N}$ Veh $45.5 \pm 4.5 \mathrm{~s}$; $2 \mathrm{~N}$ CGP $46.2 \pm 4.1 \mathrm{~s}$; Ts65Dn Veh $42.9 \pm 4.6 \mathrm{~s}$, and Ts65Dn CGP $41.9 \pm 5.6 \mathrm{~s}(p=$ $0.4-0.9)$. However, the discrimination index was significantly smaller in Ts65Dn Veh than in $2 \mathrm{~N}$ Veh group $(p=0.016$ ) (Fig. $3 D)$, suggesting an impairment of the short-term memory. Treatment with CGP55845 improved performance of Ts65Dn mice. Indeed, Ts65Dn CGP group performed significantly better than Ts65Dn Veh mice $(p=0.027)$ and did not differ from the $2 \mathrm{~N}$ CGP littermates $(p=0.77)$ (Fig. $3 D)$. Thus, hippocampusdependent short-term memory for place recognition was impaired in Ts65Dn mice, and it was restored by the $\mathrm{GABA}_{\mathrm{B}}$ receptor antagonist.

In the object recognition task, the testing was performed after replacement of one familiar object with a novel one (Fig. 3B). Similar to the previous test, all groups spent equal time exploring the objects $(p=0.4-0.7)$. However, different from the place recognition task, Ts65Dn mice showed no deficit in this behavioral test. Thus, the discrimination indexes were as follows: $2 \mathrm{~N}$ Veh $63.8 \pm 3.9$, Ts65Dn Veh $61.9 \pm 4.9(p=0.38)$ (Fig. 3F). Treatment with CGP55845 had no effect on performance of Ts65Dn $(p=0.67)$ or $2 \mathrm{~N}$ mice $(p=0.65)$ (Fig. $3 F)$. Thus, shortterm object recognition memory was spared in Ts65Dn mice, and it was not affected by the treatment.

\section{Long-term memory}

To evaluate effects of CGP55845 on long-term memory, we used two tests: novel object recognition with a retention period of $24 \mathrm{~h}$ and contextual fear conditioning with testing of cued and contextual types of memory 24 and $48 \mathrm{~h}$ after the acquisition, respectively (Fig. 4).

As was demonstrated previously, novel object recognition tests with prolonged (hours-days) retention periods depend on function of the hippocampus and, in part, the DG (Squire et al., 2007; Jessberger et al., 2009). Both acute (1-2 d) and chronic (3 weeks) effects of CGP55845 on novel object recognition have been examined (Fig. 4A,B). Of note, the acute and chronic tests were performed using different cohorts of animals and different sets of objects. Similar to previous tests, all groups of Ts65Dn and $2 \mathrm{~N}$ mice, treated with CGP55845 or vehicle, spent on average equal time exploring the objects during both the acquisition $(p=$ $0.4-0.8$ ) and the testing ( $p=0.35-0.75$ ) phases (Fig. $4 A, B$ ). Testing was performed $24 \mathrm{~h}$ after the acquisition and showed severe impairment of Ts65Dn mice after both the acute and the chronic treatment. Indeed, averaged discrimination indexes for $2 \mathrm{~N}$ Veh versus Ts65Dn Veh groups were $58.6 \pm 2.1 \%$ versus $49.9 \pm 3.2 \%(p=0.011)$ for the acute test, and $71.5 \pm 3.1 \%$ versus $55.9 \pm 4.2(p=0.006)$ for the chronic test, respectively. Treatment with CGP55845 improved performance of Ts65Dn mice in both the acute and chronic tests (Fig. $4 A, B$ ). For the acute test, the discrimination indexes in the $2 \mathrm{~N}$ CGP versus Ts65Dn CGP group were as follows: $59.7 \pm 1.7 \%$ versus $60.1 \pm 2.9 \%(p=$ $0.89)$, and for the chronic test $67.4 \pm 3.5$ versus $65.5 \pm 3.7$ ( $p=$ $0.67)$, respectively. Also, the Ts65Dn CGP group performed signifi- 
A

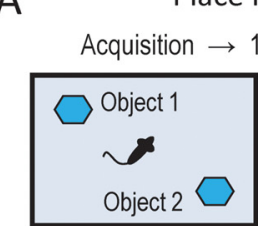

C
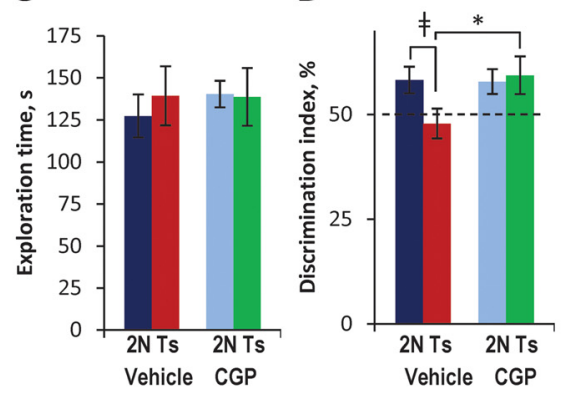

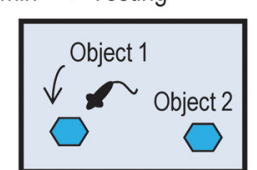

D Vehicle CGP
B

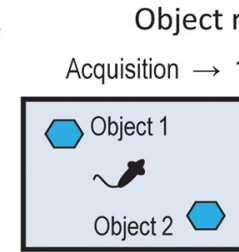

$\mathrm{E}$

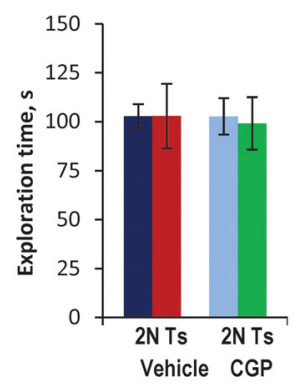

Object recogniton

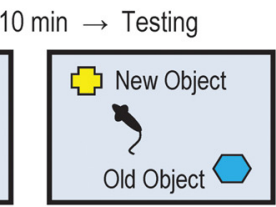

$\mathrm{F}$

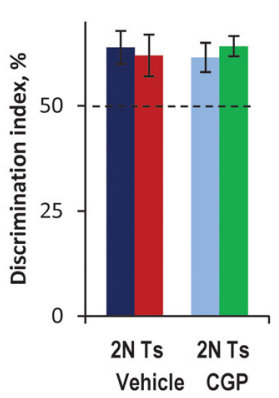

Figure 3. Effects of CGP55845 on short-term memory. $A, B$, Experimental designs for novel place recognition and novel object recognition tasks. $C$, Time spent investigating the objects during the acquisition phase in the place recognition task. There was no difference between any experimental groups. $\boldsymbol{D}$, Discrimination index in the place recognition test. Vehicle-treated Ts65Dn mice were impaired and performed at a chance level (50\%). Treatment with CGP55845 restored performance of Ts65Dn to the level of $2 \mathrm{~N}$ littermates. $\boldsymbol{E}$, Time spent investigating the objects during the acquisition phase in the object recognition task. All groups of mice spent equal time exploring the objects. $\boldsymbol{F}$, Discrimination index for the object recognition test showed no deficiency in Ts65Dn mice and no change following the treatment. ${ }^{\ddagger} p=0.016$ for $2 \mathrm{~N}$ Vehicle versus Ts65Dn Vehicle; ${ }^{*} p=0.027$ for Ts65Dn Vehicle versus Ts65Dn CGP.

A
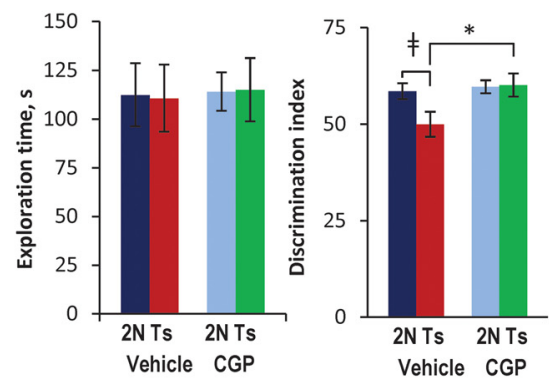

C

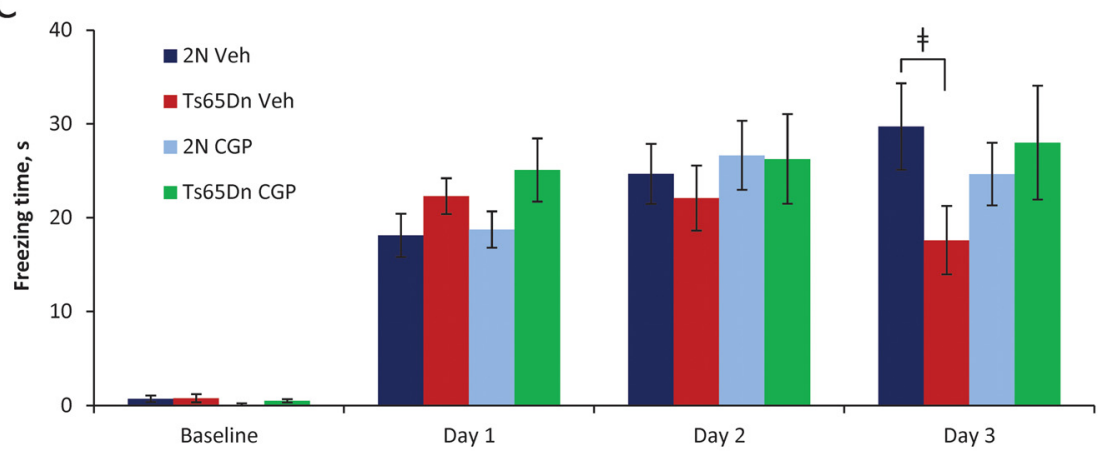

Figure 4. $G_{A B A_{B}}$ receptor antagonist improved long-term memory in Ts65Dn mice. $A$, Novel object recognition task with a retention period of $24 \mathrm{~h}$ : acute treatment with (GP55845. Left, Exploration time during the acquisition was similar in all groups. Right, The discrimination index was smaller in the Ts65Dn Veh versus $2 \mathrm{~N}$ Veh group showing impaired long-term memory of Ts65Dn mice. Treatment improved performance of Ts65Dn mice to the level of $2 \mathrm{~N}$ littermates. $\boldsymbol{B}$, Novel object recognition with a retention period of $24 \mathrm{~h}$ : chronic treatment with CGP55845. Left, Exploration time during the acquisition phase was again similar in all groups. Right, The discrimination index was reduced in the Ts65Dn Veh versus $2 \mathrm{~N}$ Veh mice. Ts65Dn mice treated with CGP55845 were not different from $2 \mathrm{~N}$ littermates. $\mathrm{C}_{,} \mathrm{GABA}_{\mathrm{B}}$ antagonist improved contextual memory in fear-conditioning test. All groups of mice showed similar performance during baseline activity before the training and during the training (day 1). Testing of cued memory (day 2) also showed no difference between the groups. In contrast, testing of contextual memory (day 3) revealed a severe deficit in the Ts65Dn vehicle control group. This deficit was not apparent in Ts65Dn mice treated with CGP55845. cantly better then the Ts65Dn Veh group in both the acute $(p=0.013)$ and chronic $(p=0.044)$ tests. Thus, both acute and chronic treatment with CGP55845 improved long-term object recognition memory in Ts65Dn mice.

We next used the contextual fear conditioning test allowing for estimation of both hippocampus-independent (cued) and hippocampus-dependent (contextual) memory (McHugh et al., 2007). After training on day 1 , Ts65Dn and $2 \mathrm{~N}$ mice underwent a test of cued learning on day 2 and contextual learning on day 3 (Fig. 4C). We found that cued memory was normal in Ts65Dn mice. Indeed, total freezing on day 2 was in $2 \mathrm{~N}$ Veh versus Ts65Dn Veh group: $24.7 \pm 3.2 \%$ versus $22.1 \pm 3.5 \%(p=0.25)$. In contrast, contextual fear memory was significantly impaired in Ts65Dn mice; total freezing on day 3 in $2 \mathrm{~N}$ Veh versus Ts65Dn Veh mice: $29.7 \pm 4.6 \%$ versus $17.6 \pm 3.6 \%(p=$ 0.039). Remarkably, treatment with the $\mathrm{GABA}_{\mathrm{B}}$ antagonist CGP55845 improved contextual fear memory in Ts65Dn mice to the level seen in $2 \mathrm{~N}$ mice. Total freezing on day 3 in 2N CGP versus Ts65Dn CGP groups was as follows: $24.6 \pm 3.3 \%$ versus $27.9 \pm 6.1 \%(p=0.61)$. The difference between Ts65Dn Veh and CGP groups also had a tendency for improvement, but the difference did not reach the level of significance $(p=0.07)$. Thus, suppressing $\mathrm{GABA}_{\mathrm{B}}$ receptors improved long-term contextual fear memory in Ts65Dn mice.

$\mathrm{GABA}_{\mathrm{B}}$ receptor antagonists increased hippocampal levels of BDNF

Enhancement of cognition by $\mathrm{GABA}_{\mathrm{B}}$ receptor antagonists can involve a number of mechanisms. It was reported that $\mathrm{GABA}_{\mathrm{B}}$ antagonists increase hippocampal levels of the BDNF (Heese et al., 2000), which is required for normal cognition (Egan et al., 2003; Nagahara and Tuszynski, 2011). To test whether or not involvement of this mechanism can explain the improvement of cognition in Ts65Dn mice, we examined BDNF levels in the hippocampus of Ts65Dn and $2 \mathrm{~N}$ mice following administration of vehicle or CGP55845 (0.5 mg/kg, i.p. injections). Hippocampal samples were collected $2 \mathrm{~h}$ after the injections. Levels of both proBDNF $(\sim 32 \mathrm{kDa})$ and mature BDNF $(\sim 15 \mathrm{kDa})$ were similar in $2 \mathrm{~N}$ and Ts65Dn mice treated with the vehicle. Treatment with CGP55845 increased levels of BDNF by about $30 \%$, but the effects were similar in $2 \mathrm{~N}$ and Ts65Dn mice (Fig. $5 A, B)$. Levels of pro-BDNF were not affected by the treatment (Fig. 5C). Thus, 

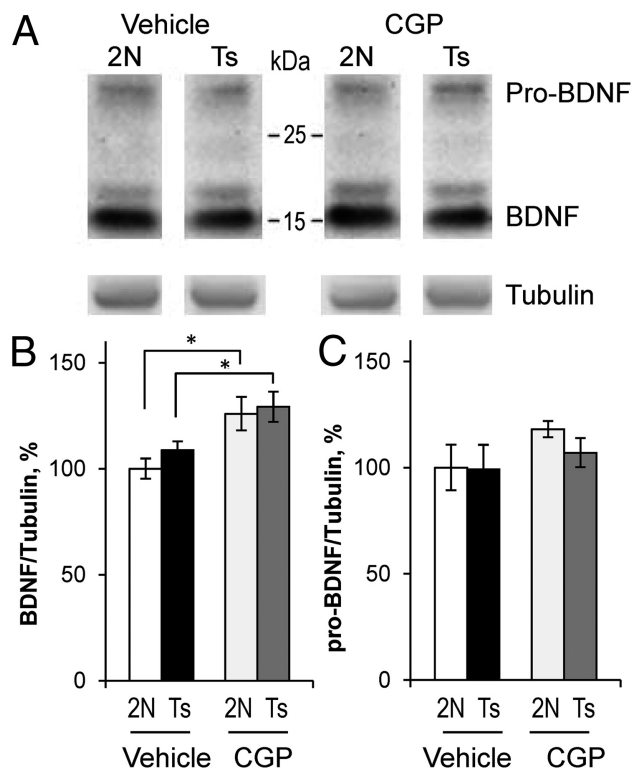

Figure 5. Hippocampal levels of proteins following treatment with CGP55845 or vehicle. $\boldsymbol{A}$, Representative Western blots of hippocampal extracts from 2N and Ts65Dn mice. B, C, Quantification of the data. Baseline levels of both mature $\operatorname{BDNF}(\boldsymbol{B})$ and pro-BDNF $(\boldsymbol{C})$ were similar in $2 \mathrm{~N}$ and Ts65Dn mice. Treatment with CGP55845 increased levels of mature BDNF in both $2 \mathrm{~N}$ and Ts65Dn mice. Tubulin was used as a reference protein. $n=4$ for all groups. ${ }^{*} p<0.03$ for $2 \mathrm{~N}$ Veh versus 2N CGP or Ts Veh versus Ts CGP.

enhancement of BDNF may contribute to the memoryenhancing efficiency of $\mathrm{GABA}_{\mathrm{B}}$ receptor antagonists. However, this effect is not specific for DS; therefore, it cannot explain selective improvement of cognition in Ts65Dn mice. This result suggests that other mechanisms that have selectivity for DS models should be involved in the improvement of cognition following treatment with the $\mathrm{GABA}_{\mathrm{B}}$ receptor antagonists.

\section{$\mathrm{GABA}_{\mathrm{B}}$ receptor antagonists enhanced LTP in the Ts65Dn DG}

Improvement of long- and short-term memory, with little or no effect on locomotion and working memory, suggests that $\mathrm{GABA}_{\mathrm{B}}$ receptor antagonists could act through enhancement of longterm synaptic plasticity. To test this suggestion, we used hippocampal slices to examine effects of $\mathrm{GABA}_{\mathrm{B}}$ receptor antagonists on LTP. The experiments were performed in the middle molecular layer of the DG, a brain region involved in the novel object recognition (Jessberger et al., 2009) and contextual part of fear conditioning memory (McHugh et al., 2007). Effects of two concentrations $(0.1$ and $1.0 \mu \mathrm{M})$ of the $\mathrm{GABA}_{\mathrm{B}}$ receptor antagonist CGP55845 were explored. $\mathrm{GABA}_{\mathrm{B}}$ receptor antagonists have $\sim 5-7$ times greater potency for postsynaptic than for presynaptic receptors (Pozza et al., 1999). For CGP55845, the reported $\mathrm{IC}_{50}$ values for postsynaptic and presynaptic $\mathrm{GABA}_{\mathrm{B}}$ receptors in hippocampal slices are 0.11 and $0.74 \mu \mathrm{M}$, respectively (Pozza et al., 1999). Thus, at the lower concentration of CGP55845 used, one would expect to suppress mostly postsynaptic receptors; at the higher concentration, both postsynaptic and presynaptic receptors would be affected. We observed that both concentrations of CGP55845 enhanced LTP in Ts65Dn DG (Fig. 6A,B). This result suggests that suppression of postsynaptic $\mathrm{GABA}_{\mathrm{B}}$ receptors plays a critical role in enhancement of LTP in Ts65Dn DG. Interestingly, only the higher concentration of CGP55845 was effective in $2 \mathrm{~N}$ slices (Fig. 6B). We tested also the effect of CGP52432, a high-affinity selective $\mathrm{GABA}_{\mathrm{B}}$ receptor antagonist with potency lower than CGP55845. At a concentration of $1 \mu \mathrm{M}$, this drug enhanced LTP in the Ts65Dn, but not in $2 \mathrm{~N}$ slices (Fig. 6C). Thus, suppression of $\mathrm{GABA}_{\mathrm{B}}$ receptors restores LTP in Ts65Dn DG.

\section{Possible mechanisms for LTP enhancement by $\mathrm{GABA}_{\mathrm{B}}$ antagonists}

Induction of LTP in the DG strongly depends on activation of NMDA receptors. Thus, one mechanism by which $\mathrm{GABA}_{\mathrm{B}}$ antagonists could increase LTP is through greater depolarization of neurons during tetanus allowing for increased activation of the NMDA receptors. To explore this possibility, we first examined the effect of CGP52432 $(1 \mu \mathrm{M})$ on field responses during tetanization (Fig. 7). Suppression of $\mathrm{GABA}_{\mathrm{B}}$ receptors significantly increased the tetanus-evoked field responses in both $2 \mathrm{~N}$ and Ts65Dn slices (Fig. 7A). To compare changes in Ts65Dn and $2 \mathrm{~N}$ slices, tetanus-evoked responses were averaged for each 10 consecutive pulses in the 50-pulse train (Fig. 7A, horizontal line with triangles) and scaled to the averaged magnitude of the first 10 responses evoked at the baseline conditions. In the absence of the drug, the responses evoked at the end of the tetanization train were smaller in Ts65Dn than in $2 \mathrm{~N}$ slices (Fig. $7 B$, white vs black bars). The difference between $2 \mathrm{~N}$ and Ts65Dn slices diminished and became insignificant $(p>0.2)$ in slices treated with CGP52432 (Fig. 7B, light gray vs dark gray bars). Since the amplitude of field responses reflects depolarization during tetanus, these data demonstrate that suppression of the $\mathrm{GABA}_{\mathrm{B}}$ receptors enhanced tetanus-evoked depolarization in Ts65Dn slices to the level of depolarization in $2 \mathrm{~N}$ slices. Such changes could possibly allow for increased activation of the NMDA receptors in Ts65Dn DG.

We next examined directly the effect of CGP52432 on the NMDA receptor-mediated component of the tetanus-evoked responses (Fig. 8). The NMDA receptor-mediated component was measured as the difference between the responses recorded before and during application of the selective NMDA receptor antagonist DL-2-amino-5-phosphonovaleric acid (DL-APV, $50 \mu \mathrm{M}$ ). These measurements were carried out before and then during application of CGP52432 (1 $\mu \mathrm{M})$. Because the first tetanization could affect the responses by inducing LTP, two tetanizations with a $10 \mathrm{~min}$ interval were applied, and the responses evoked by the second tetanus were used for analysis. At baseline conditions, the NMDA-receptor mediated responses during the tetanus (Fig. $8 A$, horizontal line with triangles) were smaller in Ts65Dn slices by about $60 \%$ (Fig. $8 \mathrm{~A}$ ). On average, the magnitude of the responses was $2 \mathrm{~N}$ : $100 \pm 9.8 \%, n=7$ and Ts65Dn: $42.72 \pm 3.5 \%$, $n=5(p=0.012)$. Application of CGP enhanced the NMDA receptor-mediated responses and eliminated the difference between $2 \mathrm{~N}$ and Ts65Dn slices (2N: $174.5 \pm 31.8, n=7$; Ts65Dn: 121.6 $\pm 28.9, n=5 ; p=0.69$ ) (Fig. $8 B$ ). These data are evidence that one mechanism by which $\mathrm{GABA}_{\mathrm{B}}$ receptor antagonists restore LTP in Ts65Dn DG is through increased depolarization of neurons during tetanus allowing for a more effective activation of the NMDA receptors.

\section{Discussion}

An important characteristic of mental retardation in DS is impairment of learning and memory. Studies of mouse genetic models have revealed that deficient learning in DS could be a result of reduced synaptic plasticity and that increased efficiency of GABAergic neurotransmission could play critical role in these abnormalities. Here we present the first evidence that antagonists of metabotropic $\mathrm{GABA}_{\mathrm{B}}$ receptors effectively improve cognition in a mouse model of DS. Administration of the $\mathrm{GABA}_{\mathrm{B}}$ receptor 
A $\quad 2 \mathrm{~N}$
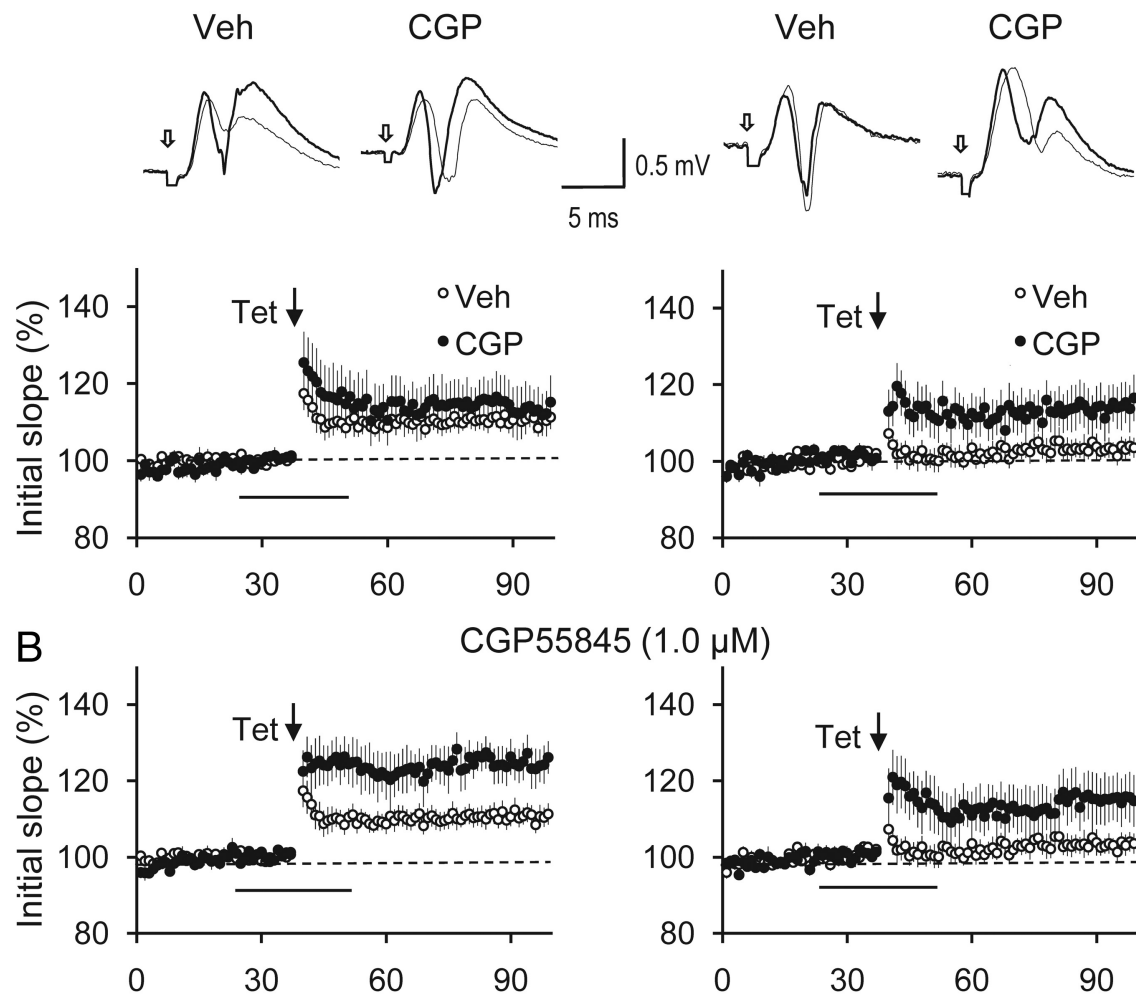

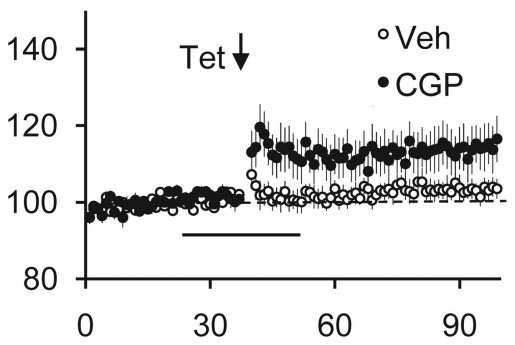

Ts65Dn

$(1.0 \mu \mathrm{M})$

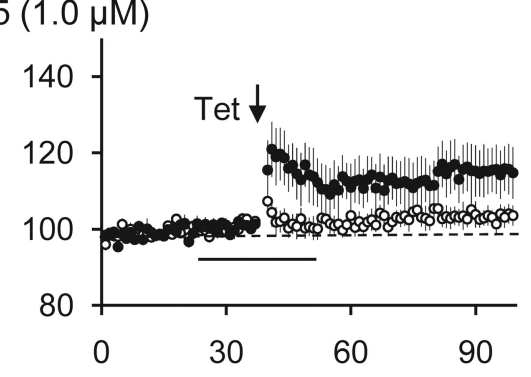

90

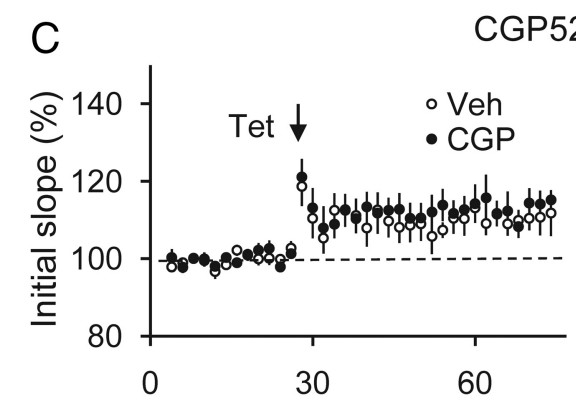

Time (min)

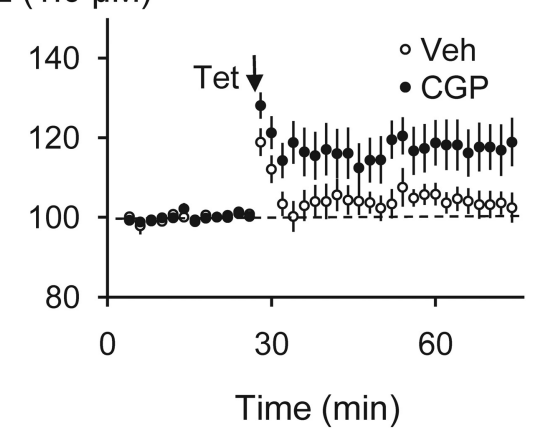

Figure 6. Enhancement of LTP by $G_{A B A}$ receptor antagonists. $A$, At baseline conditions, tetanization (Tet) evoked robust LTP in $2 \mathrm{~N}$ slices (left, empty circles), but failed to induce LTP in Ts65Dn slices (right, empty circles). Application of CGP55845 (0.1 $\mu \mathrm{M})$ significantly improved LTP in Ts65Dn slices (right, black circles), but not in 2N slices (left, black circles). Solid lines below the graphs mark the application of the drug or vehicle. Top, Representative field responses evoked $5 \mathrm{~min}$ before and $50 \mathrm{~min}$ after the tetanus (thin and thick lines, respectively) in the vehicle control (Veh) and (GP groups. B, Application of CGP55845 at higher concentration (1 $\mu \mathrm{M}$ ) enhanced LTP in both 2N and Ts65Dn slices. C, Another antagonist of the GABA ${ }_{B}$ receptors, CGP52432 (1 $\left.\mu \mathrm{M}\right)$, also enhanced LTP in the Ts65Dn slices. The drug was present in the perfusing solution during the whole period of the experiment. Mean \pm SEM; $n=8-13$.

antagonist CGP55845 resulted in improved performance of Ts65Dn mice in the place recognition test with a retention period of $10 \mathrm{~min}$ and in the novel object recognition and contextual fear conditioning tasks with retention periods of 24 and $48 \mathrm{~h}$, respectively. The treatment had no effect on locomotion, working memory, and novel object recognition with a retention period of $10 \mathrm{~min}$. The treatment increased hippocampal levels of BDNF, similarly in $2 \mathrm{~N}$ and Ts65Dn mice. Experiments on hippocampal slices showed that suppression of the $\mathrm{GABA}_{\mathrm{B}}$ receptors restored LTP and increased the NMDA receptor-mediated component of tetanus-evoked responses in Ts65Dn DG. These results point to antagonists of $\mathrm{GABA}_{\mathrm{B}}$ receptors as potential medicines for improving cognition in DS.
Enhancement of inhibitory efficiency in DS model mice was first suggested based on electrophysiological evidence (Kleschevnikov et al., 2004). Subsequent histological, morphological, and biochemical studies demonstrated numerous findings consistent with an imbalance of excitation and inhibition that favors the latter in DS model mice. Thus, it was shown that immunoreactivity of several proteins associated with GABAergic synapses, including $\mathrm{GABA}_{\mathrm{A}}$ receptor-associated protein (GABARAP), neuroligin 2, and vesicular GABA transporter, was increased in Ts65Dn mice (P.V. Belichenko et al., 2009). These changes were accompanied by alterations in the microcircuitry of inhibitory synaptic connections in Ts65Dn DG (P.V. Belichenko et al., 2004). Profound changes in the properties of inhibition were observed in the hippocampus and neocortex of neonatal Ts65Dn mice (Chakrabarti et al., 2010; Mitra et al., 2012), and the level of GAD-67 was increased in the Ts65Dn neocortex (Pérez-Cremades et al., 2010). Interestingly, in contrast to inhibition, properties of excitatory glutamatergic neurotransmission appear to be spared in the hippocampus and DG of Ts65Dn mice (Siarey et al., 1997; Kleschevnikov et al., 2004; Costa and Grybko, 2005; P.V. Belichenko et al., 2009).

Increased efficiency of the inhibitory system suggests that one strategy to improve synaptic plasticity and, perhaps, cognition in DS would be to reduce the inhibition. Indeed, nonselective antagonists of ionotropic $\mathrm{GABA}_{\mathrm{A}}$ receptors restored LTP (Kleschevnikov et al., 2004; Fernandez et al., 2007) and improved learning and memory (Fernandez and Garner, 2007b; Fernandez et al., 2007; Rueda et al., 2008) in Ts65Dn mice. Improvement of learning in Ts65Dn mice was recently demonstrated with $\alpha 5$ subunit-selective inverse agonists of the $\mathrm{GABA}_{\mathrm{A}}$ receptors (Braudeau et al., 2011a,b). One such compound is currently tested in a clinical trial (clinical identifier NCT01436955; http://www.clinicaltrials.gov). Finally, improvement of cognition in Ts65Dn mice following environmental enrichment was also linked to a decrease in GABAergic inhibition (Begenisic et al., 2011).

Here we tested another approach aimed at reducing inhibitory efficiency-blockade of metabotropic $\mathrm{GABA}_{\mathrm{B}}$ receptors. Postsynaptic $G_{A B A}$ receptors use inwardly rectifying potassium channels containing Kir3.2 subunits as effectors (Lüscher et al., 1997 ) in which gene Kcnj6 is triplicated in DS. Owing to this genetic alteration, the level of the Kir3.2 protein is increased in Ts65Dn hippocampus by about 50\% (Kleschevnikov et al., 2005, 2012a; Harashima et al., 2006). As a result, postsynaptic $\mathrm{GABA}_{\mathrm{B}} /$ Kir3.2 signaling is significantly enhanced (Best et al., 2007, 2012; Cramer et al., 2010; Kleschevnikov et al., 2012a). Importantly, 


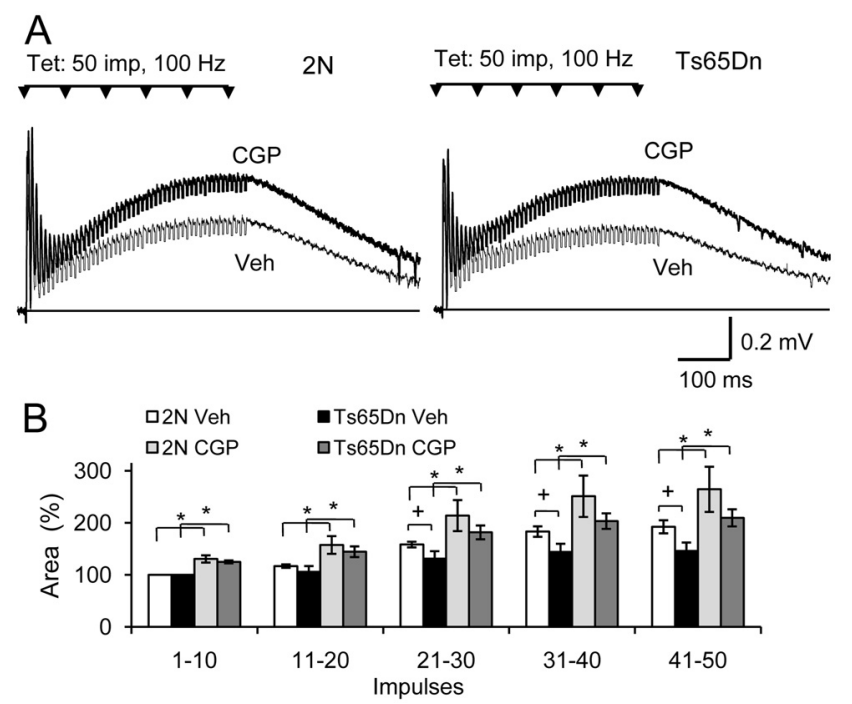

Figure 7. Suppression of $G A B A_{B}$ receptors increased tetanus-evoked fEPSPs. $\boldsymbol{A}$, Examples of tetanus-evoked field responses during application of vehicle or CGP52432 (1 $\mu \mathrm{M})$ in 2N (left) and Ts65Dn (right) slices. Horizontal lines on top mark the time of the tetani. Downward triangles indicate each 10 's pulse of the tetanization train. Stimulus artifacts are truncated. $\boldsymbol{B}$, Averaged amplitudes of responses to each 10 consecutive pulses of a 50-pulse tetanization (marked by horizontal line in $A$ ) normalized to the averaged amplitude of first 10 responses (1-10) at baseline conditions. Responses evoked during application of vehicle were smaller in Ts65Dn slices at the end of the 50-pulse train (pulses 20-50, white vs black). Application of (GP enhanced the responses in both $2 \mathrm{~N}$ and Ts65Dn slices and abolished the difference between $2 \mathrm{~N}$ and Ts65Dn slices (light gray vs dark gray). ${ }^{+} p<0.05,2 \mathrm{~N}$ Veh versus Ts65Dn Veh; ${ }^{*} p<0.01$, Veh versus CGP for 2N or Ts65Dn slices.
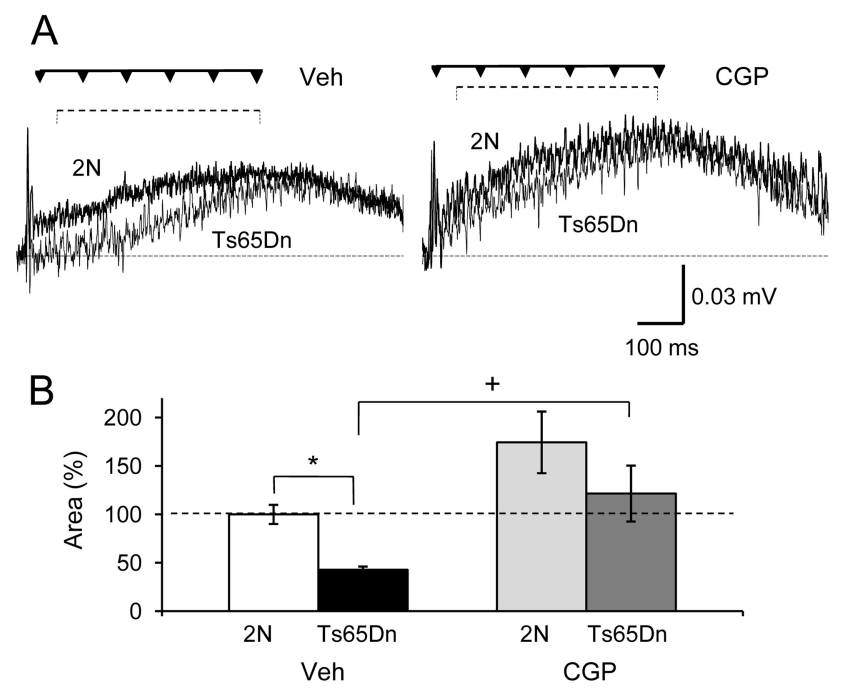

Figure 8. $\quad G_{A B A}$ receptor antagonist CGP52432 $(1 \mu \mathrm{M})$ increased the NMDA receptor-mediated component of the tetanus-evoked responses. $A$, Examples of the NMDA receptor-mediated responses in $2 \mathrm{~N}$ and Ts65Dn slices during application of vehicle (left) and CGP (right). B, Averaged data. At baseline conditions (Veh), the responses were smaller in Ts65Dn than in $2 \mathrm{~N}$ slices (graph, black vs white). Application of (GP52432 increased the responses in both 2N and Ts65Dn slices. Note that the NMDA receptor-mediated responses evoked in Ts65Dn slices during application of CGP52432 were similar to the $2 \mathrm{~N}$ Veh responses. The NMDA receptor-mediated response was evaluated as the area under the curve at latencies of $30-500 \mathrm{~ms}$ (horizontal dashed line). ${ }^{*} p=0.012$ for $2 \mathrm{~N}$ Veh versus Ts65Dn Veh; ${ }^{+} p=0.029$ Ts65Dn Veh versus Ts65Dn CGP.

$\mathrm{GABA}_{\mathrm{B}}$ receptors and Kir3.2 subunits are colocalized at extrasynaptic locations and around putative glutamatergic synapses $(\mathrm{Ku}-$ lik et al., 2003, 2006), where their presence may influence the efficiency of the excitatory neurotransmission during repetitive stimuli. Both $\mathrm{GABA}_{\mathrm{B}}$ receptors and Kir3.2 subunits are highly expressed in the hippocampus and neocortex (Murer et al., 1997; Margeta-Mitrovic et al., 1999; Charles et al., 2001; Harashima et al., 2006), brain regions critically involved in learning. It was recently shown that Kcnj6 triploid mice exhibit deficits in hippocampal dependent learning and memory as well as altered synaptic plasticity (Cooper et al., 2012). Thus, $\mathrm{GABA}_{\mathrm{B}}$ receptors may represent a promising target for pharmacotherapy of cognitive abnormality in DS.

To examine affects of $\mathrm{GABA}_{\mathrm{B}}$ receptor antagonists on cognition, we used CGP55845, a high-affinity selective $\mathrm{GABA}_{\mathrm{B}}$ antagonist exhibiting behavioral effects after intraperitoneal injections (Getova and Bowery, 1998, 2001). Suppression of $\mathrm{GABA}_{\mathrm{B}}$ receptors did not affect locomotion in $2 \mathrm{~N}$ and Ts65Dn mice. This result suggests that the enhanced hyperactivity of Ts65Dn mice is not caused by increased $\mathrm{GABA}_{\mathrm{B}} / \mathrm{Kir} 3.2$ signaling owing to triplication of the Kcnj6 gene and, for this matter, cannot be compensated by administration of $\mathrm{GABA}_{\mathrm{B}}$ receptor antagonists. Consistent with this observation, Ts1Cje mice, which also have three copies of Kcnj6, did not exhibit hyperactivity (Sago et al., 2000).

Treatment with CGP55845 significantly improved the performance of Ts65Dn mice in tasks requiring long-term memory. Novel object recognition with retention periods of $24 \mathrm{~h}$ depends in part on the hippocampus and DG (Squire et al., 2007; Jessberger et al., 2009). It was previously observed that Ts65Dn mice are severely impaired in this test (Fernandez et al., 2007), although results in other DS models were contradictory (Fernandez and Garner, 2007a; N.P. Belichenko et al., 2009). We confirmed a severe deficit of Ts65Dn mice in this task and found that treatment with CGP55845 fully reversed the deficit. Contextual fear conditioning also showed a severe abnormality in Ts65Dn mice (Costa et al., 2008; Salehi et al., 2009; Faizi et al., 2011). Treatment with CGP55845 reversed deficits in the hippocampus-dependent contextual memory and allowed Ts65Dn mice to perform at the level of $2 \mathrm{~N}$ controls.

Testing of short-term memory showed mixed results: a severe deficiency of Ts65Dn mice in place recognition task, but no change in object recognition. Because dependence from the hippocampus is stronger for place than for object recognition (Barker and Warburton, 2011), especially for short retention periods (Jessberger et al., 2009), this result additionally confirms hippocampal dysfunction in DS. Treatment with CGP55845 restored performance of Ts65Dn mice in the place recognition task. Interestingly, although working memory was also abnormal in Ts65Dn mice, it was not affected by the treatment. Thus, Ts65Dn mice mostly exhibited deficiency in hippocampus-dependent types of memory, and suppression of $\mathrm{GABA}_{\mathrm{B}}$ receptors restored the short- and long-term types of memory.

One mechanism by which antagonists of $\mathrm{GABA}_{\mathrm{B}}$ receptors might improve cognition is through elevation of hippocampal levels of BDNF (Heese et al., 2000). We found that acute treatment with CGP55845 enhanced levels of both pro-BDNF and mature BDNF. However, this enhancement was similar in $2 \mathrm{~N}$ and Ts65Dn mice, suggesting that the effect has no specificity for DS.

The improvement of short- and long-term types of memory, but not working memory, suggests that the underlying cellular mechanisms may involve modulation of synaptic plasticity. It was previously demonstrated that suppression of the $\mathrm{GABA}_{\mathrm{B}}$ receptors may enhance LTP (Mott and Lewis, 1991; Olpe et al., 1993; Stäubli et al., 1999), and that such enhancement correlated positively with learning (Stäubli et al., 1999). Consistent with such a possibility, we observed that CGP55845 and CGP52432, 
two high-affinity selective antagonists of the $\mathrm{GABA}_{\mathrm{B}}$ receptors, improved LTP in Ts65Dn slices. Because postsynaptic GABA $_{B}$ receptors play an essential role in the regulation of NMDA receptor-mediated synaptic responses (Morrisett et al., 1991; Chalifoux and Carter, 2010), we investigated the NMDA receptor-mediated component of field responses during tetanus. This component was significantly smaller in Ts65Dn DG thus providing a plausible link to reduced LTP. The $\mathrm{GABA}_{\mathrm{B}}$ antagonist increased the NMDA receptor-mediated component in Ts65Dn slices to the level seen in the untreated $2 \mathrm{~N}$ slices. Thus, enhanced activation of the NMDA receptors represents one possible mechanism by which $\mathrm{GABA}_{\mathrm{B}}$ receptor antagonists increased LTP.

Besides improvement of synaptic plasticity, a number of additional mechanisms can be envisioned to explain the facilitatory effects of $\mathrm{GABA}_{\mathrm{B}}$ antagonists on learning and memory. Thus, suppression of presynaptic $\mathrm{GABA}_{\mathrm{B}}$ receptors on terminals of somatostatin-containing GABAergic neurons may increase the release of somatostatin (Nyitrai et al., 2003), which positively affects learning and memory (Bennett et al., 1997; Kluge et al., 2008). $\mathrm{GABA}_{\mathrm{B}}$ antagonists also increased responsiveness to exogenously applied acetylcholine (Andre et al., 1992), suggesting that suppression of $\mathrm{GABA}_{\mathrm{B}}$ receptors could augment cholinergic function that, in turn, may affect learning. Finally, $\mathrm{GABA}_{\mathrm{B}}$ receptors on presynaptic terminals of glutamatergic fibers effectively modulate release of glutamate. Suppression of these receptors may enhance efficiency of the excitatory signaling and, thus, also contribute to the effects of the $\mathrm{GABA}_{\mathrm{B}}$ receptor antagonists. The role of these receptors in DS remains to be investigated.

It was shown previously that $\mathrm{GABA}_{\mathrm{B}}$ receptor antagonists improved performance of normal animals in a number of behavioral tests (Mondadori et al., 1993; Stäubli et al., 1999; Getova and Bowery, 2001; Froestl et al., 2004; Helm et al., 2005). In this study, we observed improvement only in Ts65Dn mice, while performance of $2 \mathrm{~N}$ mice remained unchanged. This result might suggest that, in our experimental conditions, the performance of $2 \mathrm{~N}$ mice was close to biological limits and, for this matter, could not be improved. On the other hand, it is possible that DS-specific genetic alterations of Ts65Dn mice enhance receptivity of these subjects to the treatment. Thus, antagonists of $\mathrm{GABA}_{\mathrm{B}}$ receptors may represent a class of drugs selectively effective in subjects with DS.

Taken together, the data presented in this study suggest that suppression of the $\mathrm{GABA}_{\mathrm{B}}$ receptor-mediated signaling is an effective way for improving synaptic plasticity and cognition in mouse models of DS. These findings motivate studies to test therapeutic efficiency of $\mathrm{GABA}_{\mathrm{B}}$ receptor antagonists in people with DS.

\section{References}

Andre P, Ferrat T, Steinman M, Olpe HR (1992) Increased acetylcholine and quisqualate responsiveness after blockade of GABAB receptors. Eur J Pharmacol 218:137-143.

Barker GR, Warburton EC (2011) When is the hippocampus involved in recognition memory? J Neurosci 31:10721-10731.

Begenisic T, Spolidoro M, Braschi C, Baroncelli L, Milanese M, Pietra G, Fabbri ME, Bonanno G, Cioni G, Maffei L, Sale A (2011) Environmental enrichment decreases GABAergic inhibition and improves cognitive abilities, synaptic plasticity, and visual functions in a mouse model of Down syndrome. Front Cell Neurosci 5:29.

Belichenko NP, Belichenko PV, Kleschevnikov AM, Salehi A, Reeves RH, Mobley WC (2009) The "Down syndrome critical region" is sufficient in the mouse model to confer behavioral, neurophysiological, and synaptic phenotypes characteristic of Down syndrome. J Neurosci 29:5938-5948.

Belichenko PV, Masliah E, Kleschevnikov AM, Villar AJ, Epstein CJ, Salehi A,
Mobley WC (2004) Synaptic structural abnormalities in the Ts65Dn mouse model of Down Syndrome. J Comp Neurol 480:281-298.

Belichenko PV, Kleschevnikov AM, Salehi A, Epstein CJ, Mobley WC (2007) Synaptic and cognitive abnormalities in mouse models of Down syndrome: exploring genotype-phenotype relationships. J Comp Neurol 504:329-345.

Belichenko PV, Kleschevnikov AM, Masliah E, Wu C, Takimoto-Kimura R, Salehi A, Mobley WC (2009) Excitatory-inhibitory relationship in the fascia dentata in the Ts65Dn mouse model of Down syndrome. J Comp Neurol 512:453-466.

Bennett GW, Ballard TM, Watson CD, Fone KC (1997) Effect of neuropeptides on cognitive function. Exp Gerontol 32:451-469.

Best TK, Siarey RJ, Galdzicki Z (2007) Ts65Dn, a mouse model of Down syndrome, exhibits increased GABAB-induced potassium current. J Neurophysiol 97:892-900.

Best TK, Cramer NP, Chakrabarti L, Haydar TF, Galdzicki Z (2012) Dysfunctional hippocampal inhibition in the Ts65Dn mouse model of Down syndrome. Exp Neurol 233:749-757.

Bevins RA, Besheer J (2006) Object recognition in rats and mice: a one-trial non-matching-to-sample learning task to study 'recognition memory.' Nat Protoc 1:1306-1311.

Bowes C, Li T, Frankel WN, Danciger M, Coffin JM, Applebury ML, Farber DB (1993) Localization of a retroviral element within the rd gene coding for the beta subunit of cGMP phosphodiesterase. Proc Natl Acad Sci U S A 90:2955-2959.

Braudeau J, Dauphinot L, Duchon A, Loistron A, Dodd RH, Hérault Y, Delatour B, Potier MC (2011a) Chronic treatment with a promnesiant GABA-A alpha5-selective inverse agonist increases immediate early genes expression during memory processing in mice and rectifies their expression levels in a Down syndrome mouse model. Adv Pharmacol Sci 2011:153218.

Braudeau J, Delatour B, Duchon A, Pereira PL, Dauphinot L, de Chaumont F, Olivo-Marin JC, Dodd RH, Hérault Y, Potier MC (2011b) Specific targeting of the GABA-A receptor alpha5 subtype by a selective inverse agonist restores cognitive deficits in Down syndrome mice. J Psychopharmacol 25:1030-1042.

Carlesimo GA, Marotta L, Vicari S (1997) Long-term memory in mental retardation: evidence for a specific impairment in subjects with Down's syndrome. Neuropsychologia 35:71-79.

Chakrabarti L, Best TK, Cramer NP, Carney RS, Isaac JT, Galdzicki Z, Haydar TF (2010) Olig1 and Olig2 triplication causes developmental brain defects in Down syndrome. Nat Neurosci 13: 1927-1934.

Chalifoux JR, Carter AG (2010) GABAB receptors modulate NMDA receptor calcium signals in dendritic spines. Neuron 66:101-113.

Charles KJ, Evans ML, Robbins MJ, Calver AR, Leslie RA, Pangalos MN (2001) Comparative immunohistochemical localisation of GABA(B1a), GABA(B1b) and GABA(B2) subunits in rat brain, spinal cord and dorsal root ganglion. Neuroscience 106:447-467.

Colombo G, Melis S, Brunetti G, Serra S, Vacca G, Carai MA, Gessa GL (2001) GABA(B) receptor inhibition causes locomotor stimulation in mice. Eur J Pharmacol 433:101-104.

Contestabile A, Benfenati F, Gasparini L (2010) Communication breaksDown: from neurodevelopment defects to cognitive disabilities in Down syndrome. Prog Neurobiol 91:1-22.

Cooper A, Grigoryan G, Guy-David L, Tsoory MM, Chen A, Reuveny E (2012) Trisomy of the G protein-coupled K+ channel gene, Kcnj6, affects reward mechanisms, cognitive functions, and synaptic plasticity in mice. Proc Natl Acad Sci U S A 109:2642-2647.

Costa AC, Grybko MJ (2005) Deficits in hippocampal CA1 LTP induced by TBS but not HFS in the Ts65Dn mouse: a model of Down syndrome. Neurosci Lett 382:317-322.

Costa AC, Scott-McKean JJ, Stasko MR (2008) Acute injections of the NMDA receptor antagonist memantine rescue performance deficits of the Ts65Dn mouse model of Down syndrome on a fear conditioning test. Neuropsychopharmacology 33:1624-1632.

Cramer NP, Best TK, Stoffel M, Siarey RJ, Galdzicki Z (2010) GABABGIRK2-mediated signaling in Down syndrome. Adv Pharmacol 58:397-426.

Davisson MT, Schmidt C, Reeves RH, Irving NG, Akeson EC, Harris BS, Bronson RT (1993) Segmental trisomy as a mouse model for Down syndrome. Prog Clin Biol Res 384:117-133. 
Dierssen M, Fillat C, Crnic L, Arbonés M, Flórez J, Estivill X (2001) Murine models for Down syndrome. Physiol Behav 73:859-871.

Egan MF, Kojima M, Callicott JH, Goldberg TE, Kolachana BS, Bertolino A, Zaitsev E, Gold B, Goldman D, Dean M, Lu B, Weinberger DR (2003) The BDNF val66met polymorphism affects activity-dependent secretion of BDNF and human memory and hippocampal function. Cell 112:257-269.

Faizi M, Bader PL, Tun C, Encarnacion A, Kleschevnikov A, Belichenko P, Saw N, Priestley M, Tsien RW, Mobley WC, Shamloo M (2011) Comprehensive behavioral phenotyping of Ts65Dn mouse model of down syndrome: activation of beta(1)-adrenergic receptor by xamoterol as a potential cognitive enhancer. Neurobiol Dis 43:397-413.

Fernandez F, Garner CC (2007a) Object recognition memory is conserved in Ts1Cje, a mouse model of Down syndrome. Neurosci Lett 421:137-141.

Fernandez F, Garner CC (2007b) Over-inhibition: a model for developmental intellectual disability. Trends Neurosci 30:497-503.

Fernandez F, Morishita W, Zuniga E, Nguyen J, Blank M, Malenka RC, Garner CC (2007) Pharmacotherapy for cognitive impairment in a mouse model of Down syndrome. Nat Neurosci 10:411-413.

Froestl W, Gallagher M, Jenkins H, Madrid A, Melcher T, Teichman S, Mondadori CG, Pearlman R (2004) SGS742: the first GABA(B) receptor antagonist in clinical trials. Biochem Pharmacol 68:1479-1487.

Galdzicki Z, Siarey RJ (2003) Understanding mental retardation in Down's syndrome using trisomy 16 mouse models. Genes Brain Behav 2:167-178.

Gardiner K, Herault Y, Lott IT, Antonarakis SE, Reeves RH, Dierssen M (2010) Down syndrome: from understanding the neurobiology to therapy. J Neurosci 30:14943-14945.

Getova D, Bowery NG (1998) The modulatory effects of high affinity GABA(B) receptor antagonists in an active avoidance learning paradigm in rats. Psychopharmacology (Berl) 137:369-373.

Getova DP, Bowery NG (2001) Effects of high-affinity GABAB receptor antagonists on active and passive avoidance responding in rodents with gamma-hydroxybutyrolactone-induced absence syndrome. Psychopharmacology (Berl) 157:89-95.

Gotti S, Caricati E, Panzica G (2011) Alterations of brain circuits in Down syndrome murine models. J Chem Neuroanat 42:317-326.

Hanson JE, Blank M, Valenzuela RA, Garner CC, Madison DV (2007) The functional nature of synaptic circuitry is altered in area CA3 of the hippocampus in a mouse model of Down's syndrome. J Physiol 579:53-67.

Harashima C, Jacobowitz DM, Witta J, Borke RC, Best TK, Siarey RJ, Galdzicki Z (2006) Abnormal expression of the G-protein-activated inwardly rectifying potassium channel 2 (GIRK2) in hippocampus, frontal cortex, and substantia nigra of Ts65Dn mouse: a model of Down syndrome. J Comp Neurol 494:815-833.

Haydar TF, Reeves RH (2012) Trisomy 21 and early brain development. Trends Neurosci 35:81-91.

Heese K, Otten U, Mathivet P, Raiteri M, Marescaux C, Bernasconi R (2000) $\mathrm{GABA}(\mathrm{B})$ receptor antagonists elevate both $\mathrm{mRNA}$ and protein levels of the neurotrophins nerve growth factor (NGF) and brain-derived neurotrophic factor (BDNF) but not neurotrophin-3 (NT-3) in brain and spinal cord of rats. Neuropharmacology 39:449-462.

Helm KA, Haberman RP, Dean SL, Hoyt EC, Melcher T, Lund PK, Gallagher M (2005) GABAB receptor antagonist SGS742 improves spatial memory and reduces protein binding to the cAMP response element (CRE) in the hippocampus. Neuropharmacology 48:956-964.

Holtzman DM, Santucci D, Kilbridge J, Chua-Couzens J, Fontana DJ, Daniels SE, Johnson RM, Chen K, Sun Y, Carlson E, Alleva E, Epstein CJ, Mobley WC (1996) Developmental abnormalities and age-related neurodegeneration in a mouse model of Down syndrome. Proc Natl Acad Sci U S A 93:13333-13338.

Hyde LA, Frisone DF, Crnic LS (2001) Ts65Dn mice, a model for Down syndrome, have deficits in context discrimination learning suggesting impaired hippocampal function. Behav Brain Res 118:53-60.

Incerti M, Toso L, Vink J, Roberson R, Nold C, Abebe D, Spong CY (2011) Prevention of learning deficit in a Down syndrome model. Obstet Gynecol 117:354-361.

Jessberger S, Clark RE, Broadbent NJ, Clemenson GD Jr, Consiglio A, Lie DC, Squire LR, Gage FH (2009) Dentate gyrus-specific knockdown of adult neurogenesis impairs spatial and object recognition memory in adult rats. Learn Mem 16:147-154.

Kleschevnikov AM, Belichenko PV, Villar AJ, Epstein CJ, Malenka RC, Mobley WC (2004) Hippocampal long-term potentiation suppressed by in- creased inhibition in the Ts65Dn mouse, a genetic model of Down syndrome. J Neurosci 24:8153-8160.

Kleschevnikov AM, Van Volkinburg J, Zhan K, Mobley WC (2005) Expression of GIRK2 and related proteins after chronic administrations of Prozac in Ts65Dn mice, a genetic model of Down syndrome. Soc Neurosci Abstr 31:115.7.

Kleschevnikov AM, Belichenko PV, Gall J, George L, Nosheny R, Maloney MT, Salehi A, Mobley WC (2012a) Increased efficiency of the GABAA and GABAB receptor-mediated neurotransmission in the Ts65Dn mouse model of Down syndrome. Neurobiol Dis 45:683-691.

Kleschevnikov AM, Belichenko PV, Salehi A, Wu C (2012b) Discoveries in Down syndrome: moving basic science to clinical care. Prog Brain Res 197:199-221.

Kluge C, Stoppel C, Szinyei C, Stork O, Pape HC (2008) Role of the somatostatin system in contextual fear memory and hippocampal synaptic plasticity. Learn Mem 15:252-260.

Kulik A, Vida I, Luján R, Haas CA, López-Bendito G, Shigemoto R, Frotscher M (2003) Subcellular localization of metabotropic GABA(B) receptor subunits $\mathrm{GABA}(\mathrm{B} 1 \mathrm{a} / \mathrm{b})$ and $\mathrm{GABA}(\mathrm{B} 2)$ in the rat hippocampus. J Neurosci 23:11026-11035.

Kulik A, Vida I, Fukazawa Y, Guetg N, Kasugai Y, Marker CL, Rigato F, Bettler B, Wickman K, Frotscher M, Shigemoto R (2006) Compartmentdependent colocalization of Kir3.2-containing $\mathrm{K}+$ channels and GABAB receptors in hippocampal pyramidal cells. J Neurosci 26:4289-4297.

Liu C, Belichenko PV, Zhang L, Fu D, Kleschevnikov AM, Baldini A, Antonarakis SE, Mobley WC, Yu YE (2011) Mouse models for Down syndrome-associated developmental cognitive disabilities. Dev Neurosci 33:404-413.

Lott IT, Dierssen M (2010) Cognitive deficits and associated neurological complications in individuals with Down's syndrome. Lancet Neurol 9:623-633.

Lüscher C, Jan LY, Stoffel M, Malenka RC, Nicoll RA (1997) G proteincoupled inwardly rectifying $\mathrm{K}+$ channels (GIRKs) mediate postsynaptic but not presynaptic transmitter actions in hippocampal neurons. Neuron 19:687-695.

Margeta-Mitrovic M, Mitrovic I, Riley RC, Jan LY, Basbaum AI (1999) Immunohistochemical localization of $\mathrm{GABA}(\mathrm{B})$ receptors in the rat central nervous system. J Comp Neurol 405:299-321.

McHugh TJ, Jones MW, Quinn JJ, Balthasar N, Coppari R, Elmquist JK, Lowell BB, Fanselow MS, Wilson MA, Tonegawa S (2007) Dentate gyrus NMDA receptors mediate rapid pattern separation in the hippocampal network. Science 317:94-99.

Mitra A, Blank M, Madison DV (2012) Developmentally altered inhibition in Ts65Dn, a mouse model of Down syndrome. Brain Res 1440:1-8.

Mondadori C, Jaekel J, Preiswerk G (1993) CGP 36742: the first orally active GABAB blocker improves the cognitive performance of mice, rats, and rhesus monkeys. Behav Neural Biol 60:62-68.

Moore CS, Roper RJ (2007) The power of comparative and developmental studies for mouse models of Down syndrome. Mamm Genome 18:431-443.

Morrisett RA, Mott DD, Lewis DV, Swartzwelder HS, Wilson WA (1991) GABAB-receptor-mediated inhibition of the $N$-methyl-D-aspartate component of synaptic transmission in the rat hippocampus. J Neurosci 11:203-209.

Mott DD, Lewis DV (1991) Facilitation of the induction of long-term potentiation by GABAB receptors. Science 252:1718-1720.

Murer G, Adelbrecht C, Lauritzen I, Lesage F, Lazdunski M, Agid Y, RaismanVozari R (1997) An immunocytochemical study on the distribution of two G-protein-gated inward rectifier potassium channels (GIRK2 and GIRK4) in the adult rat brain. Neuroscience 80:345-357.

Nadel L (2003) Down's syndrome: a genetic disorder in biobehavioral perspective. Genes Brain Behav 2:156-166.

Nagahara AH, Tuszynski MH (2011) Potential therapeutic uses of BDNF in neurological and psychiatric disorders. Nat Rev Drug Discov 10:209-219.

Nyitrai G, Kékesi KA, Emri Z, Szárics E, Juhász G, Kardos J (2003) GABA(B) receptor antagonist CGP-36742 enhances somatostatin release in the rat hippocampus in vivo and in vitro. Eur J Pharmacol 478:111-119.

Olpe HR, Steinmann MW, Ferrat T, Pozza MF, Greiner K, Brugger F, Froestl W, Mickel SJ, Bittiger H (1993) The actions of orally active GABAB receptor antagonists on GABAergic transmission in vivo and in vitro. Eur J Pharmacol 233:179-186.

Olson LE, Roper RJ, Sengstaken CL, Peterson EA, Aquino V, Galdzicki Z, 
Siarey R, Pletnikov M, Moran TH, Reeves RH (2007) Trisomy for the Down syndrome 'critical region' is necessary but not sufficient for brain phenotypes of trisomic mice. Hum Mol Genet 16:774-782.

Pérez-Cremades D, Hernández S, Blasco-Ibáñez JM, Crespo C, Nacher J, Varea E (2010) Alteration of inhibitory circuits in the somatosensory cortex of Ts65Dn mice, a model for Down's syndrome. J Neural Transm 117:445-455.

Popov VI, Kleschevnikov AM, Klimenko OA, Stewart MG, Belichenko PV (2011) Three-dimensional synaptic ultrastructure in the dentate gyrus and hippocampal area CA3 in the Ts65Dn mouse model of down syndrome. J Comp Neurol 519:1338-1354.

Pozza MF, Manuel NA, Steinmann M, Froestl W, Davies CH (1999) Comparison of antagonist potencies at pre- and post-synaptic GABA(B) receptors at inhibitory synapses in the CA1 region of the rat hippocampus. Br J Pharmacol 127:211-219.

Reeves RH (2006) Down syndrome mouse models are looking up. Trends Mol Med 12:237-240.

Rueda N, Flórez J, Martínez-Cué C (2008) Chronic pentylenetetrazole but not donepezil treatment rescues spatial cognition in Ts65Dn mice, a model for Down syndrome. Neurosci Lett 433:22-27.

Sago H, Carlson EJ, Smith DJ, Rubin EM, Crnic LS, Huang TT, Epstein CJ (2000) Genetic dissection of region associated with behavioral abnormalities in mouse models for Down syndrome. Pediatr Res 48:606-613.

Salehi A, Faizi M, Belichenko PV, Mobley WC (2007) Using mouse models to explore genotype-phenotype relationship in Down syndrome. Ment Retard Dev Disabil Res Rev 13:207-214.

Salehi A, Faizi M, Colas D, Valletta J, Laguna J, Takimoto-Kimura R, Kleschevnikov A, Wagner SL, Aizen P, Shamloo M, Mobley WC (2009) Restoration of norepinephrine-modulated contextual memory in a mouse model of Down syndrome. SciTransl Med 1:7ra17.
Shichiri M, Yoshida Y, Ishida N, Hagihara Y, Iwahashi H, Tamai H, Niki E (2011) alpha-Tocopherol suppresses lipid peroxidation and behavioral and cognitive impairments in the Ts65Dn mouse model of Down syndrome. Free Radic Biol Med 50:1801-1811.

Siarey RJ, Stoll J, Rapoport SI, Galdzicki Z (1997) Altered long-term potentiation in the young and old Ts65Dn mouse, a model for Down Syndrome. Neuropharmacology 36:1549-1554.

Squire LR, Wixted JT, Clark RE (2007) Recognition memory and the medial temporal lobe: a new perspective. Nat Rev Neurosci 8:872-883.

Stäubli U, Scafidi J, Chun D (1999) GABAB receptor antagonism: facilitatory effects on memory parallel those on LTP induced by TBS but not HFS. J Neurosci 19:4609-4615.

Sturgeon X, Gardiner KJ (2011) Transcript catalogs of human chromosome 21 and orthologous chimpanzee and mouse regions. Mamm Genome 22:261-271.

Sylvester PE (1983) The hippocampus in Down's syndrome. J Ment Defic Res 27:227-236.

Vicari S (2001) Implicit versus explicit memory function in children with Down and Williams syndrome. Downs Syndr Res Pract 7:35-40.

Yu T, Liu C, Belichenko P, Clapcote SJ, Li S, Pao A, Kleschevnikov A, Bechard AR, Asrar S, Chen R, Fan N, Zhou Z, Jia Z, Chen C, Roder JC, Liu B, Baldini A, Mobley WC, Yu YE (2010) Effects of individual segmental trisomies of human chromosome 21 syntenic regions on hippocampal long-term potentiation and cognitive behaviors in mice. Brain Res 1366:162-171.

Zhang L, Fu D, Belichenko PV, Liu C, Kleschevnikov AM, Pao A, Liang P, Clapcote SJ, Mobley WC, Yu YE (2012) Genetic analysis of Down syndrome facilitated by mouse chromosome engineering. Bioeng Bugs $3: 8-12$. 